Participants in the criminal procedure. St. Petersburg., 2015, 176 p. (In Russ.)]

5.Методические рекомендации по реализации прав адвоката, предусмотренных п. 2 ч. 1 ст. 53, ч. 3ст. 86 УПК РФ и п. 3 ст. 6 Федерального закона «Об адвокатской деятельности и адвокатуре в Российской Федерации» [Электронный ресурс]. ФЕДЕРАЛЬНАЯ ПАЛАТА АДВОКАТОВ РОССИЙСКОЙ ФЕДЕРАЦИИ [ОфициальНЫЙ сайт]. URL: https://fparf.ru/ (дата обращения: 15.05.2020).

6.Шейфер С. А. Следственные действия. Основания, процессуальный порядок и доказательственное значение. М., 2004. С. 79 [Shejfer S. A. Investigative actions. Grounds, procedural order and evidentiary value. M., 2004. 115 p.]

\title{
CRIMINAL LAW: MODERN CHALLENGES
}

DOI: $\frac{10.31618 / \text { ESU.2413-9335.2020.2.74.741 }}{\text { Serebrennikova Anna } V .}$
Doctor of law, Professor of criminal law and criminology
Moscow state University. M. V. Lomonosov

Russia, Moscow

\begin{abstract}
ANNOTATION
Mission: To analyze the main trends related to the digitalization of criminal law in the most discussed areas, to analyze and summarize the positions of researchers regarding the construction of norms on responsibility for computer crimes in the domestic criminal legislation. Reflect the main areas of use of artificial intelligence in the process of qualification of crimes and law enforcement. Consider the use of information technologies in the educational process when training specialists for law enforcement agencies. As a result of the research, the authors conclude that the achievements of recent years in the field of digital technologies have created not only a number of new problems with crime, but also contributed to the prevention, detection, investigation, prosecution and punishment of crime. However, many issues related to their use in criminal law have remained unresolved. Today, the science of criminal law is faced with the task of developing a model of systemic updating of domestic criminal legislation, the effectiveness of which directly depends on the ability of the legislator to perceive trends in the field of information technology and crime challenges. The author's view on the actual problem in criminal law science is presented. The results of the study and the conclusions formulated in this article can be used in the educational process when studying the Sciences of the criminal law cycle in higher education institutions.
\end{abstract}

Keywords: Digital technologies; criminal law; qualification of crimes; artificial intelligence; digitalization; computer crimes.

The transformative effect of digital and communication technologies on modern society has been attracting increasing attention of legal scholars around the world. Since the workstations for personal computers first came into existence in the early 1980s, since the launch of the global Internet in 1991, and to date, numerous studies have been conducted in the field of criminal law. These studies indicate that digitalization acts as a catalyst for cross-border criminal activities [3, p. 32].

On the other hand, the development of digital technologies helps one to effectively counter crime. Databases, which accumulate evidence in criminal cases, are increasingly being used in forensics and criminal procedure; algorithmization and automation of many processes take place, and even artificial intelligence (hereinafter - AI) is used in making procedural decisions. Digital technologies are actively used in the process of teaching criminal legal disciplines in the training of personnel of law enforcement authorities and judges.

In the national legislation, the constituent elements of computer-related crimes have not only been enshrined in Chapter 28 of the Criminal Code of the Russian Federation, but have been dispersed throughout the whole of its Special Part. It appears that the concept of "computer-related crimes" covers any socially dangerous actions, in which the AI can be engaged, and also any information technologies and opportunities, arising from their use. Examples may include both long-known crimes (hacking virus crimes, computer attacks, such as "denial of service", Internet fraud, online threats, distribution of digital images of child pornography, theft of confidential information on the Internet), and quite new types of criminal actions, which have not found their way into the criminal law (wrongful acts using face swap technology, quasimoney turnover, etc.).

The opinions of researchers were divided into two opposite groups with respect to the issue of elaboration of criminal legal prohibitions in the environment of digitalization. Some authors propose to implement the criminalization of crimes using digital technologies in a fragmented manner, by introducing corresponding changes into the general constituent elements of crimes [8]. Many studies in this area still remain focused primarily on the law enforcement activities and investigations, on the legal framework and motivation of cybercriminals, often in the context of individual and "rational" theories of criminals, who only seek to explain the technology as a tool for committing other crimes, which have long been known to the criminal law [4, p. 54]. Other researchers classify computerrelated crimes into a separate group, substantiating this by the necessity for a comprehensive resolution of this problem, since it is not possible to adapt the Special Part of the Criminal Code of the Russian Federation to the conditions of information society by constructing "virtual copies", "digital twins" of the traditional criminal legal prohibitions [9]. 
Issues related to the acquisition of independent legal status by AI are actively discussed in the national criminal legal doctrine. Scholars recognize AI as a complex, artificially created software and hardware system, capable of acquiring and analysing information, as well as of self-learning [6, c.43]. The legal science pays comparatively serious attention to the issue of risks and uncertainties associated with the use of AI [7, p. 102]. Some researchers consider that AI has already risen to such a level that in Russia it is necessary to adopt a special codified act in the field of robotic engineering [2, p. 53].

In our opinion, at the present time, consideration of AI as a subject of a crime can only entail negative consequences, since law violators will use robots for their criminal purposes, while remaining unpunished. However, if a physical artificial intelligence carrier is completely independent of the person in his (her) actions and decisions, acquires the ability to comprehend his (her) behaviour, and assess its possible consequences, it will be possible to reason of the criminal responsibility of such a subject.

The increasing role of information technologies and the potential for their use in the process of making legally relevant decisions has formed an animated debate in the legal science with respect to whether AI can qualify the actions of the guilty person correctly and impose punishment, which corresponds to the degree of social danger of the actions committed, the purposes of which will finally be achieved.

Studies in the field of application of AI in the qualification of crimes are conducted in many countries. Thus, back in 1996, a group of researchers of the M.V. Lomonosov Moscow State University created a computer programme to assess crimes committed using with the use of weapons [5, p. 54]. It appears that the development of such algorithms has future prospects; however engagement of leading specialists in the theory and practice of the criminal law will be required. The algorithm for the qualification of a crime can be built on a deductive principle, by answering the questions that will cut off the concepts with unnecessary content.

However, it is commonly known that, the scope of criminal law is replete with evaluative attributes. Collisions in the qualification of actions in cases of extreme necessity indicate that at the present time people themselves are still undecided as to the value priorities, not to speak of whether AI is capable of resolving this issue. At the moment, along with the norm of extreme necessity, the criminal law immediately requires a norm of forced alternative harm.

A similar question arises in literature and practice with respect to the qualification of actions with in cases of necessary defence. The priority of human life over public relations in the domain of property is proclaimed at the legislative and doctrinal levels. Indeed, in practice, the infliction of grievous bodily harm or death to a person who tried to secretly or openly steal other people's property is usually qualified as the use of excessive force in self-defence. However, there are precedents where actions in response to the offence against property, which entailed grievous bodily harm or death, are qualified as lawful actions (for example, actions of cash-in-transit couriers in case of offence against the property of a bank). The reasonable question here is how AI will act in a similar case.

The issues on the possibility of criminal legal assessment of AI of a minor criminal action, imposition of punishment, which does not involve deprivation of liberty, determination of the necessity of a conditional sentence, etc., are the issues that are no less important in the context of this study.

It appears that the issue on the active legal capacity and possibility to use $\mathrm{AI}$ in the qualification of crimes are inextricably linked. It is the possibility of AI's consciousness of its own actions that indicates that AI is capable of qualifying people's wrongful behaviour.

That is why we agree with many researchers who express the opinion about the possibility of the coexistence of $\mathrm{AI}$ and human discretion in the decisionmaking process with respect to the qualification of a crime [10, p. 178]. In any case, under the current conditions we do not see other constructive solutions to the problem concerned.

Modern forensic science has not yet developed any theories that could clearly predict in advance the commission of a crime by a particular person. Predictive (perspective) analysis is a complex process, which uses large volumes of data to forecast and formulate the potential results. In the sphere of criminal law, this work is mainly the work of internal affairs authorities, practicing and other specialists who should obtain experience throughout the years.

With the use of AI, the volumes of information on the law and legal priority, social information and mass media can be used to elaborate solutions, detect criminal organizations, as well as to predict and detect people running a risk of criminal offences. The scholars working with the support of the Research Centre for Problems in Regulation of Robotics and AI (ANO Robopravo. Research Centre for Problems in Regulation of Robotics and Artificial Intelligence [Electronic resource] // Access: http://robopravo.ru/ (Date of reference: 03.03.2020)) are developing computational approaches to the explanation and interpretation, which can potentially increase the rate and quality of recognition of oral speech obtained as a result of the use of technical audio-recording facilities in the criminal procedure. The researches make a hypothesis that a computer program can automatically recognize certain types of statements, which play the most important role in legal interpretation. The objective is to develop a proven concept of an expert system to support a legal position and to execute it automatically to qualify crimes.

Artificial intelligence is also able to analyse large volumes of information of criminal legal value to predict a possible repetition of the crime. The existing automated search systems contain large volumes of information, the analysis of which can potentially predict the risks of repetition of the crime by the fugitives from justice.

Artificial intelligence can also help one to detect potential elderly victims of profit-motivated and domestic violence. Foreign researchers of the University of Texas Health Science Center at Houston, USA, used the AI algorithms to analyse the victimization of elderly people [1, p. 7]. The algorithms can detect a victim, a criminal and objective factors, which promote to financial exploitation and other 
forms of cruel treatment of elderly people. They also can distinguish between the "pure" financial exploitation (where the actions of the guilty person consist merely in the seizure of property) form the "hybrid" financial exploitation (where financial exploitation with respect to the victim includes the use of physical abuse or other actions, which humiliate human dignity). The researchers hope that these data algorithms can be transformed into software packages, in order to make it possible for the officers of law enforcement authorities to reliably determine the likelihood of occurrence of financial exploitation and operatively prevent the criminal activity. (Exploring Elder Financial Exploitation Victimization" at the University of Texas Health Science Center at Houston, NIJ award number 2013-IJ-CX-0050 URL: https://nij.ojp.gov/funding/awards/2013-ij-cx-0050).

Criminal law is actively developing as an academic discipline. Against the backdrop of the global development of transnational computer-related crime, law enforcement authorities are experiencing the ever increasing need for highly-qualified specialists who are able to effectively use the most important technological developments. Effective activities of law enforcement authorities are not possible without the use of information and legal technologies. The use of electronic library systems (elibrary.ru, Юрайт, cyberleninka.ru), inquiry and communications system (СПС «Консультант Плюс», «Гарант»), and other Internet resources (sudact.ru) has become a compulsory element in the training of lawyers in higher and secondary education programs, as well as in professional retraining. A particular group consists of distance education technologies, which are being gradually implemented at the specialized educational institutions of law enforcement authorities.

Having considered some aspects of the possible use of digitalization in jurisprudence, we should point out that this phenomenon is evaluated by representatives of various fields as either a negative phenomenon or is highly appreciated. On the one hand, jurisprudence and the sphere of criminal law also apprehend their implementation into the sphere of computer technologies, while on the other hand, they are called to regulate and protect legal relations (such as intellectual rights on the Internet, cybercrime, etc.) in this area. Digitalization causes anxiety among many scholars who consider that the computer will eventually replace the human. It appears that at the present stage the application of AI is not possible in the spheres, which require the manifestation of creative activities, which are common to human behaviour.

As far as computer-related crimes are concerned, it appears that at the present stage the criminal legal science is faced with the task of developing a model for systemic update of the national criminal legislation. In our opinion, the effectiveness of this process directly depends on the ability of the legislator to perceive trends in the sphere of information technologies and challenges of crime.

\section{References}

1. Arkhipov V.V., Naumov V.B. Iskusstvennyi intellekt $\mathrm{i}$ avtonomnye ustroistva $\mathrm{v}$ kontekste prava: $\mathrm{o}$ razrabotke pervogo v Rossii zakona o robototekhnike [Artificial intelligence and Autonomous devices in the context of law: development of the first law on robotics in Russia] Trudy SPIIRAN [Works of SPIIRAN]. 2017. no. 6, pp. 46-62. (In Russian)

2. Afanas'ev A.Yu. Iskusstvennyi intellekt ili intellekt sub"ektov vyyavleniya, raskrytiya i rassledovaniya prestuplenii: chto pobedit? [Artificial intelligence or intelligence of subjects of detection, disclosure and investigation of crimes: which will win?], Biblioteka kriminalista. Nauchnyi zhurnal. 2018, no. 3, (38). pp. 28-34. (In Russian)

3. Gavrilova Yu. A. Pravoprimenitel'naya praktika: osobennosti smysloobrazovaniya [Law enforcement practice: features of meaning formation] Zhurnal rossiiskogo prava [Journal of Russian law]. 2018, № 5. S. 54. (In Russian)

4. Inogamova-Khegai L.V. Kvalifikatsiya prestuplenii s ispol'zovaniem komp'yuternykh tekhnologii [Qualification of crimes using computer technologies] Ugolovnoe pravo: strategiya razvitiya $\mathrm{v}$ XXI veke: Materialy XVI Mezhdunarodnoi nauchnoprakticheskoi konferentsii [Criminal law: development strategy in the XXI century: Proceedings of the XVI International scientific and practical conference] M., 2019. pp.51-55 (In Russian)

5. Kamyshanskii V.P., Koretskii A.V. Ponyatie i pravovoi status nositelya iskusstvennogo intellekta [Concept and legal status of an artificial intelligence carrier] Vlast' Zakona [Rule of law] 2019, № 1 (37). S. 42-50. (In Russian)

6. Ponkin I.V., Red'kina A.I. Iskusstvennyi intellekt $\mathrm{s}$ tochki zreniya prava [Artificial intelligence from the point of view of law] Vestnik Rossiiskogo universiteta druzhby narodov. Seriya: Yuridicheskie nauki [Bulletin Of the Russian University of peoples ' friendship. Series: Legal Sciences.] 2018, T. 22. № 1. pp. 91-109. (In Russian)

7. Rassolov I. M. Kiberprestupnost': ponyatie, osnovnye cherty, formy proyavleniya [Cybercrime: concept, main features, forms of manifestation] Yuridicheskii mir. Obshcherossiiskii nauchnoprakticheskii pravovoi zhurnal [Legal world. AllRussian scientific and practical legal journal] 200, № 2 (134) // SPS «Konsul'tant-Plyus». (In Russian)

8. Russkevich E.A. O tsifrovizatsii Osobennoi chasti UK RF [About digitalization of a Special part of the criminal code of the Russian Federation] Vestnik Moskovskogo universiteta MVD Rossii [Bulletin of the Moscow University of the Ministry of internal Affairs of Russia] 2019, №1. URL: https://cyberleninka.ru/article/n/o-tsifrovizatsiiosobennoy-chasti-uk-rf (data obrashcheniya: 02.03.2020). (In Russian)

9. Shchelkonogova E.V. Ugolovnoe pravo online: teoriya i praktika tsifrovizatsii [Criminal law online: theory and practice of digitalization] Tekhnologii XXI veka v yurisprudentsii Materialy Vserossiiskoi nauchno-prakticheskoi konferentsii. Pod redaktsiei D.V. Bakhteeva [Technologies of the XXI century in law Materials of the all-Russian scientific and practical conference. Edited by D. V. Bakhteev.] 2019, pp. 177181. (In Russian) 